\title{
Two syntactic positions of grammatical gender
}

\author{
Olga Steriopolo \\ Independent scholar \\ olgasteriopolo@hotmail.com
}

\begin{abstract}
The paper proposes some formal and functional criteria for distinguishing between two different syntactic positions of grammatical gender: determiner gender $(D$ gender) and nominal gender ( $n$-gender). Focusing on $D$-gender and how it differs from $n$-gender, this work supports previous analyses of gender as a heterogeneous category that occupies different positions in the syntactic tree. Data are presented from 27 languages, many of which are either critically endangered or already extinct. ${ }^{1}$
\end{abstract}

Keywords: linguistics; morphosyntax; grammatical gender; noun class; endangered languages.

\section{Introduction}

Gender and noun class are systems of nominal classification which are based on grammatical agreement, to which they give rise (see, e.g., Dixon 1982: 211; Aikhenvald 2000: 21; Grinevald 2000: 56). Following Aikhenvald (2000: 19) and Grinevald (2000: 57), I treat gender and noun class as the same basic type using the term "gender" for both. Classifiers, on the other hand, do not trigger grammatical agreement; thus, they are not treated as gender and fall outside the scope of the present study (but see, e.g., Seifart 2010, Corbett and Fedden 2016, and Fedden and Corbett 2017 for a discussion of the issue of there not always being a clear-cut distinction between classifiers and nouns classes across languages).

There is a range of literature claiming that gender is a syntactically heterogeneous category which occupies different positions in the syntactic tree

\footnotetext{
${ }^{1}$ This research was supported by a DFG (German Research Foundation) research grant to Olga Steriopolo (4/2016 - 3/2019).
} 
(e.g., Alexiadou 2004; Armoskaite and Wiltschko 2012; Fassi Fehri 2015; Pesetsky 2013; Steriopolo and Wiltschko 2010; Steriopolo 2017, 2018a). Here, I focus on two different syntactic positions: the nominalizing head (what I call " $n$-gender") and the determiner head (what I call " $D$-gender'). Although there are elaborate studies of $n$-gender across languages (e.g., Lecarme 2002 for Somali; Ferrari 2005 and Kihm 2005 for Bantu and Romance; Lowenstamm 2008 for French and Yiddish; Acquaviva 2009 for Italian; Kramer 2012 for Amharic), there appears to be a drastic lack of research on $D$-gender and no clear criteria for distinguishing between $n$-gender and $D$ gender (however, see Armoskaite and Wiltschko 2012 for the argument that different types of gender correspond to different types of nominal Aspect).

\section{A puzzle}

In Sare, a Papuan language spoken in the Sepik River basin of northern Papua New Guinea, gender can vary according to the size and shape of the referent (Sumbuk 1999). Small, short, or rounded referents are usually feminine, while big, tall, or slender referents are usually masculine, as in (1).

(1a) sebox-r

table-MASC

'high table'

(3b) sebox-u

table-FEM

'squat table'

(Sumbuk 1999: 115)

In the Harar dialect of Oromo, an East Cushitic language spoken in Ethiopia and Kenya, gender can vary to indicate the speaker's emotions (Clamons 1995). For example, in (2b), the speaker's negative attitude towards a dog is shown by changing the usually feminine gender of the noun 'dog' to masculine.

(2a) Sareé takka ganda xeesa arkinne.

dog.FEM one.FEM village in we.saw

'We saw a dog in the neighborhood.' 
(2b)

\begin{tabular}{|c|c|c|}
\hline $\begin{array}{l}\text { Sareé-n } \\
\text { dog-MASC.SUBJ.TOPIC }\end{array}$ & $\begin{array}{l}\text { xun } \\
\text { that.MASC }\end{array}$ & $\begin{array}{l}\text { bashoo } \\
\text { cat.FEM }\end{array}$ \\
\hline fige. & & \\
\hline my.FEM after ran.M & & \\
\hline
\end{tabular}

(Clamons 1995: 392)

In a wide range of languages from the Sepik region (e.g., the Ndu, KwomaNukuma, and Sepik Hill families) as well as many Afroasiatic languages (Cushitic, Omotic, Amharic), gender variation is used productively as a means to indicate the physical form of the referent (e.g., size or shape) or to express the speaker's emotions (see Aikhenvald 2012 for a detailed description of Papuan languages and di Garbo 2013 on African languages).

In contrast, among Indo-European languages, there is no variation in gender that would depend on the visual form of a referent (with the exception of diminutive and augmentative affixes that can change the gender of the base to which they attach). For example, the word for 'sun' is masculine in French (3a), neuter in Russian (3b), and feminine in German (3c), although all three cultures presumably perceive the sun as having the same size and shape.

(3a) le

soleil (*la soleil)

DET.MASC.SG sun.MASC.SG

'the sun'

(3b) solnc-e

sun-NEUT.SG

'the sun'

(3c) die

$\begin{array}{lll}\text { die } & \text { Sonne } & \text { (*der Sonne; *das Sonne) } \\ \text { DET.FEM.SG } & \text { sun.FEM.SG } \\ \text { the sun,2 } & \end{array}$

The following questions arise. First, how can we account for variation in gender in some languages and the absence thereof in others? And second, how can we explain the direct dependency of gender on the visual form of a referent in some languages and the absence of such a dependency in others?

${ }^{2}$ Examples without references are my own. 


\section{A proposal}

I propose that the difference between languages with variation in gender and those with no variation (the ones that have so-called "fixed" gender) is directly related to the different syntactic positions occupied by the category "gender" across languages. I further propose that fixed gender is generated on the nominal head ( $n$-gender), while variable gender is generated on the determiner head ( $D$-gender), as shown in the structure ${ }^{3}$ in (4).

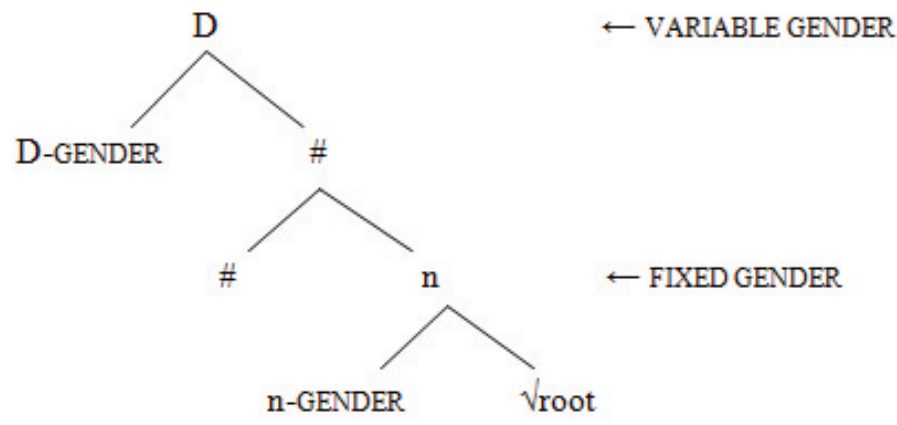

Thus, the first characteristic that distinguishes the different types of gender ( $n$-gender vs. $D$-gender) is variation: $n$-gender is fixed, while $D$-gender is variable. The second characteristic is discourse dependency: $n$-gender is independent of discourse, while $D$-gender is directly dependent (the dependence on discourse will be discussed in Section 4). The two proposed characteristics are summarized in Table 1.

Table 1. Characteristics for n-gender and D-gender.

\begin{tabular}{lll}
\hline & n-GENDER & D-GENDER \\
\hline Discourse-dependent & $*$ & $\checkmark$ \\
Fixed & $\checkmark$ & $*$ \\
\hline
\end{tabular}

\footnotetext{
${ }^{3}$ The notation ' $\sqrt{ }$ ' is from Pesetsky (1995).
} 
For gender systems which are predominantly fixed (n-gender systems), as in many Indo-European languages, it is appropriate to talk about a change in gender or "overriding" of gender (the term is from Corbett 1991). For example, in (5b), the German word Tisch 'table' changes gender from masculine to neuter when the diminutive suffix -chen is attached. This produces a difference in grammatical agreement with the determiner: the masculine determiner der in (5a) and the neuter determiner das in (5b).

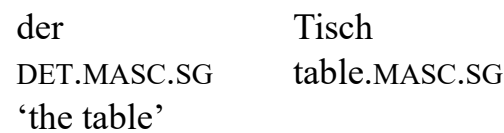

$\begin{array}{ll}\text { das } & \text { Tisch-chen } \\ \text { DET.NEUT.SG } & \text { table-DIM } \\ \text { 'the little table' } & \end{array}$

For gender systems which are predominantly variable ( $D$-gender systems), the use of the term "overriding" of gender would be inaccurate, as in such languages, nouns have no fixed gender; thus, the term "variation in gender" is more apt.

My proposal assumes the underlying universal DP-hierarchy diagrammed in (6) (Acquaviva 2018, based on the critical overview in Svenoni-

(6)

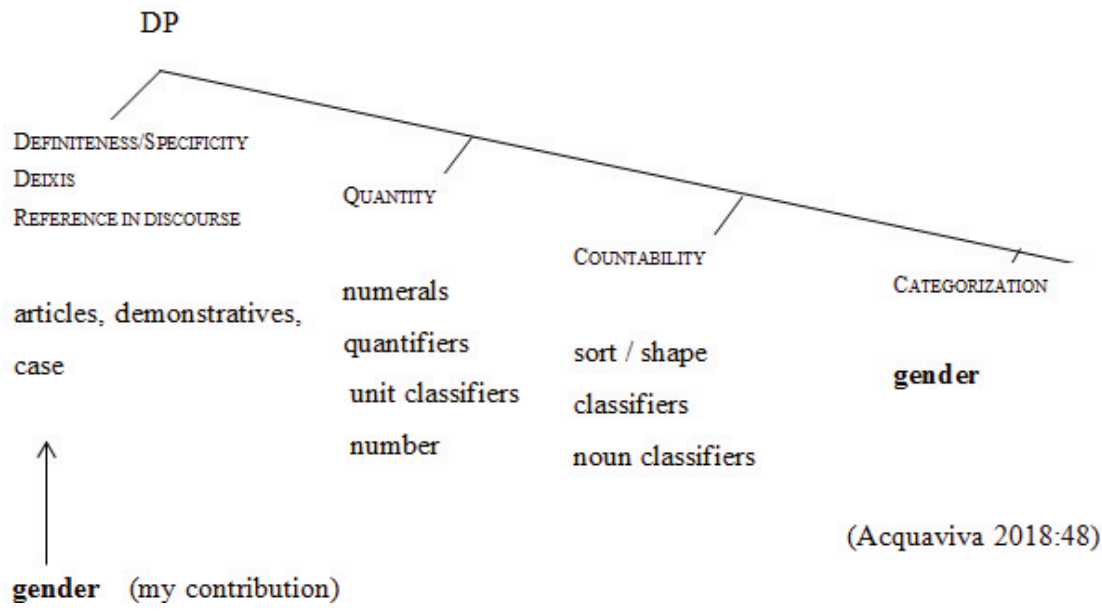


us 2008). Notice that "gender" (in bold) is placed under the categorization node, which corresponds to the $n$-gender in a labeled syntactic tree. My contribution to this DP-hierarchy is an additional position for gender (shown with an arrow), placed under the discourse node and thus corresponding to the $D$-gender in a labeled tree.

The structure in (6) makes a number of functional and formal predictions, described in (7) and (8) respectively. In the following sections these predictions will be shown to be borne out cross-linguistically.

(7) Functional predictions

(a) Correlation of D-gender and deixis.

(b) Correlation of D-gender and referentiality.

(8) Formal predictions

(a) Double-marking of gender should be possible.

(b) Mixed gender should be possible.

(c) Separate, independent gender systems within a single language should be possible.

\section{Functional predictions}

\subsection{Deixis}

According to Fillmore (1971), the major grammaticalized types of deixis are those of person, place, and time. Here, I focus on person deixis, discussing the speech-act participants, i.e., the speaker and the addressee.

Haas (1944: 147) distinguishes between three different types of gender systems based on the sex of speech-act participants: (i) the speaker-based system, (ii) the addressee-based system, and (iii) the speaker-and-addressee based system. In addition to significant phonological differences between female and male speech, morphological and lexical differences are also attested. Here, I focus on morphological differences, specifically, on variation in gender/noun class.

\subsubsection{Speaker-based system}

Yanyuwa, an endangered Pama-Nyungan language spoken in northern Australia, uses noun class prefixes which differ depending on the sex of the speaker (Dunn 2014). Female speakers use two different noun classes, 
"male" and "masculine", as in Table 2, while male speakers use a single noun class, as in Table 3.

Table 2. Noun class prefixes in the female dialect of Yanyuwa.

\begin{tabular}{lll}
\hline Noun class & Nominative & Non-nominative \\
\hline male & $n y a-$ & $n y u-$ \\
masculine & $\varnothing$ & $j i-$ \\
\hline
\end{tabular}

(Dunn 2014: 51)

Table 3. Noun class prefixes in the male dialect of Yanyuwa.

\begin{tabular}{lll}
\hline Noun class & Nominative & Non-nominative \\
\hline male/masculine & $\varnothing$ & $k i-$ \\
\hline
\end{tabular}

(Dunn 2014: 51)

Gerdts (2013) reports that in Halkomelem (an endangered Central Salish language spoken in southwestern British Columbia, Canada), the same inanimate noun can appear with either feminine or non-feminine determiners, depending on the sex of the speaker. Males tend to use non-feminine determiners (9a), while females tend to use feminine determiners (9b).

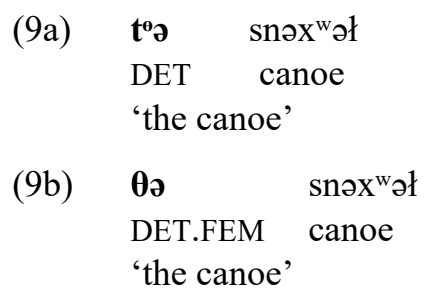

(Gerdts 2013: 420)

In a dialect of Awetí (an endangered indigenous language of Central Brazil), the morphological distinction between female and male speech manifests itself in the differences in some of the personal pronouns and prefixes as well as all the demonstratives, as shown in Table 4. 
Table 4. Female versus male forms in Awetí: A selection.

\begin{tabular}{lll}
\hline Translation & \multicolumn{2}{l}{ Female form Male form } \\
\hline First person singular pronoun & itó & atit \\
Third person singular pronoun & $\tilde{\imath}$ & $n \tilde{a}$ \\
Third person plural pronoun & $t a$ 'i & $t s \tilde{a}$ \\
Proximal demonstrative 'this' (close to speaker) & $u j a ́$ & $j a t \tilde{a}$ \\
Proximal demonstrative 'this' (close to addressee) & $a k y ́ j$ & $k i t \tilde{a}$ \\
Distal demonstrative 'that' (distant from both speaker & $a k o ́ j$ & $k u j t \tilde{a}$ \\
and addressee) & & \\
\hline
\end{tabular}

(Aikhenvald 2016: 140)

\subsubsection{Addressee-based system}

Haas (1944: 148) observes that the addressee-based system is uncommon across languages. One example of such a system, however, is Tunica, a now extinct Native American isolate, which was still spoken at the time of Mary Haas's work in Louisiana.

In Tunica, the difference between female and male speech lies in the pronominal system and consists of the use of different independent pronouns, prefixes, and suffixes. The difference is maintained for three numbers (singular, dual, and plural), as illustrated in Table 5. The choice of these forms is based on the sex of the addressee. If, for example, the addressee is male, the pronominal suffix $-? a$ is used in the singular. If the addressee is female, the suffix $-P i$ is used.

Table 5. Male and female speech determined by the sex of the addressee in Tunica.

\begin{tabular}{lllll}
\hline & $\begin{array}{l}\text { Sex of } \\
\text { addressee }\end{array}$ & Singular & Dual & Plural \\
\hline Pronominal suffixes on & Man & $-P a$ & $-w i^{\prime} n a$ & $-w i^{\prime} t i$ \\
semelfactive verbs & Woman & $-P i$ & $-h i^{\prime} n a$ & $-h i^{\prime} t i$ \\
\hline Independent pronouns & Man & $m a ́$ & wi'nima & \\
& Woman & $h^{h}$ 'ma & hi'nima & \\
\hline
\end{tabular}

(Aikhenvald 2016: 142) 


\subsubsection{Speaker-and-addressee-based system}

The speaker-and-addressee system has been identified in Yana (an extinct isolate formerly spoken in northern California), Biloxi (an extinct Siouan language), and Kũrux (a Dravidian language spoken in northern India). In these languages, the distinction between female and male forms depends on the sex of the speaker and the sex of the addressee. Although there are multiple phonological and morphological differences between female and male forms in these languages (see Aikhenvald 2016: 139, 141; Haas 1944: 149), I am not aware of any differences concerning the use of gender markers. For this reason, I will leave such languages for further research.

\subsection{Referentiality}

In many languages of the world, gender markers directly depend on the "speaker's cognitive construal of a referent" (Payne 1998: 168). For example, in many Papuan (Aikhenvald 2012) and Afroasiatic (di Garbo 2013) languages, the use of gender markers for inanimate or non-human nouns directly depends on how the speaker views the referent (the gender of [+human] nouns correlates with the sex of the referent). In (10), I list the major factors that can trigger variation in gender based on the speaker's cognitive construal of a referent.

(10a) Physical form (e.g., size/shape/orientation/dimensionality) of a referent.

(10b) Distance to a referent.

(10c) Emotions of the speaker towards a referent.

\subsubsection{Physical form of a referent}

Aikhenvald (2012: 66) provides a detailed description of variation in gender based on the physical form of a referent. In Table 6, we observe that round, squat, and horizontal referents are usually feminine across languages, while narrow, elongated, and vertical referents are usually masculine. In terms of size, many (but not all) languages associate feminine gender with smallness, while some other languages (e.g., Tiwi, Mali, Cantabrian Spanish) associate it with largeness. 
Table 6. Physical properties in feminine and masculine gender assignment.

\begin{tabular}{|c|c|c|}
\hline Feminine & Masculine & Languages (selection) \\
\hline short, squat, wide & $\begin{array}{l}\text { big, tall, long, } \\
\text { slender }\end{array}$ & $\begin{array}{l}\text { Languages of the Sepik region (including } \\
\text { Manambu, Iatmul and Gala from the Ndu } \\
\text { family, Kwoma from the Kwoma- } \\
\text { Nukuma family, and Alamblak and Sare } \\
\text { from the Sepik Hill family); Afroasiatic } \\
\text { languages (Cushitic, Omotic, Amharic } \\
\text { [Semitic]); Eastern Nilotic; Khwe } \\
\text { (Central Khoisan) }\end{array}$ \\
\hline small, flat & $\begin{array}{l}\text { large, three- } \\
\text { dimensional }\end{array}$ & Abau (isolate, New Guinea area) \\
\hline large, wide, round & small, straight, thin & Tiwi (Australian region) \\
\hline larger & smaller & $\begin{array}{l}\text { Mali (Baining); Yonggom (Ok); Olo } \\
\text { (Torricelli); Hamar (Omotic) }\end{array}$ \\
\hline $\begin{array}{l}\text { larger, wide, } \\
\text { horizontal, squat }\end{array}$ & $\begin{array}{l}\text { smaller, narrow, } \\
\text { vertical, tall }\end{array}$ & Cantabrian Spanish \\
\hline
\end{tabular}

(Aikhenvald 2012: 66)

For example, in Manambu, a Ndu language of the Sepik River region of northern Papua New Guinea, the word for 'pig' is used with the masculine suffix - $d \partial$ if the speaker views it as large, and the feminine suffix - $\varnothing$ if the speaker views it as small (independent of the sex of the animal) (see Aikhenvald 2012: 44), as given in (11).

\begin{tabular}{|c|c|}
\hline (11a) & $\begin{array}{l}\text { numa-də } \\
\text { big-MASC.SG } \\
\text { 'big nig' }\end{array}$ \\
\hline (11b) & $\begin{array}{l}\text { kwasa-ø } \\
\text { small-FEM.SG }\end{array}$ \\
\hline
\end{tabular}

(Aikhenvald 2012: 44)

In Maale, the masculine gender suffix can be used as an augmentative and the feminine suffix as a diminutive (Amha 2001), as shown in (12a, b). 
(12a) Máár-átsí maz3-ínt-éne.

house-MASC.NOM build-PASSIVE-VERB

'The big house is built (augmentative).'

(12b) Yénnó mís'-ell-ó dóngo Pas-á

that.FEM.ABS tree-FEM-ABS five person.PL-N

bukínti wolla túg-áne.

gather together uproot-VERB

'Five people gather together and uproot that small tree (diminutive).'

(Amha 2001: 71)

In contrast, the feminine gender is associated with largeness in Hadza, an endangered isolate spoken in Tanzania (Edenmyr 2004), as well as in Tiwi, an Australian Aboriginal language spoken on the Tiwi Islands (Osborne 1974), as indicated in (13) and (14), respectively.

(13a) ?ato

axe.MASC

'axe'

(13b) Pato-ko

axe-FEM

'large axe'

(Edenmyr 2004: 16)

(14a) waliwali-ni

ant-MASC

'small ant'

(14b) waliwali-na

ant-FEM

'large ant'

(Osborne 1974: 51)

\subsubsection{Distance to a referent}

In Arawak (or Lokono Dian), a language spoken by the Lokono people of South America, nouns and pronouns are classified according to the features 
[+/-human] and [+/-male] (Pet 2011). However, these features "do not necessarily reflect whether or not a referent is human or male in an objective sense; instead they may reflect the speaker's feelings toward a referent" (Pet 2011: 14). A referent is classified as [+human] if it is a member of the Arawak group and [-human] if it is not. The so-called social distance of a referent is also considered: if the speaker considers a referent to be a close friend, although from a different ethnic group, the human gender can be used to express unity with that indigenous group, as in (15). The male gender can be used not only for male individuals from the Arawak group, but also to express warm feelings towards a referent, for example, toward a small human infant (male or female, Arawak or not). Speaker's emotions are discussed in the following subsection.

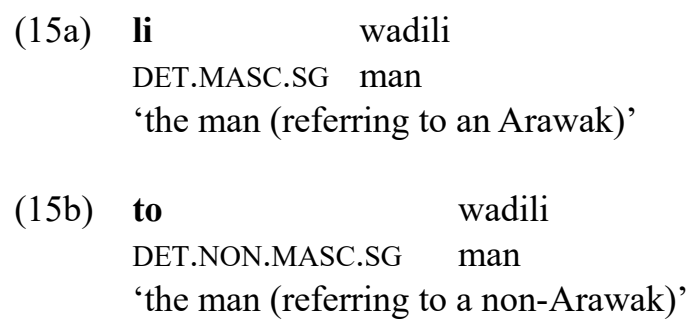

Arawak demonstrative pronouns and adjectives, as well as articles, are differentiated according to the referent's physical and social distance from the speaker, as shown in Table 7 (next page).

Ngandi, an extinct Australian Aboriginal language that was spoken in the Northern Territory, exhibited [+human] and [-human] noun classes (Heath 1978: Ch. 4), as illustrated in Table 8 (next page). The [-human] $a$ - prefix could be used on nouns denoting foreigners (indefinite persons), such as $m u$ naya 'White'. However, the $a$ - prefix would not be used to refer to a specific individual, e.g., for a white man living at the settlement (Heath 1978: Ch. 4).

In Guugu Yimidhirr, an Australian language spoken on the Cape York Peninsula, every individual belongs to one of two great groups (or moieties), each of which has a representative totem animal (Haviland 1979: 213). From a man's perspective, for example, his moiety is the one to which he himself, his children, and his father belong, while the other moiety is the one to which

\footnotetext{
4 "Social distance" is my term; Pet (2011) uses the term "psychological distance".
} 
Table 7. Demonstrative pronouns, demonstrative adjectives, and articles

\begin{tabular}{lllllll}
\hline & \multicolumn{3}{c}{$\begin{array}{l}\text { Singular non- } \\
\text { masculine human }\end{array}$} & $\begin{array}{l}\text { Singular masculine } \\
\text { human }\end{array}$ & Plural human \\
\hline $\begin{array}{l}\text { Neutral distance article } \\
\text { or demonstrative } \\
\text { adjective }\end{array}$ & to & 'the' & $l i$ & 'the' & $n a$ & 'the' \\
$\begin{array}{l}\text { Neutral distance } \\
\text { demonstrative } \\
\text { adjectives or pronoun }\end{array}$ & toho & 'this' & lihi & 'this' & naha & 'these' \\
$\begin{array}{l}\text { Slightly distant } \\
\text { demonstrative } \\
\text { adjective or pronoun }\end{array}$ & tora & 'that' & lira & 'that' & nara & 'those' \\
$\begin{array}{l}\text { Distant demonstrative } \\
\text { adjective or pronoun }\end{array}$ & toraha & 'that' & liraha & 'that' naraha & 'those' \\
$\begin{array}{l}\text { Distant pointing } \\
\text { demonstrative } \\
\text { adjective/pronoun }\end{array}$ & torabo & $\begin{array}{l}\text { 'that } \\
\text { there' }\end{array}$ & lirabo & $\begin{array}{l}\text { 'that } \\
\text { there' }\end{array}$ & narabo & $\begin{array}{l}\text { 'those } \\
\text { there' }\end{array}$ \\
\hline
\end{tabular}

(Pet 2011: 15)

Table 8. Ngandi noun-class prefixes.

\begin{tabular}{lll}
\hline & Class & Prefix \\
\hline Human & masculine singular & $n i-$ \\
& feminine singular & $n a-$ \\
& masculine dual & $b a r i-$ \\
& plural (including feminine dual & $b a-$ \\
& and mixed masculine/feminine) & \\
\hline Non-human & NI class & $n i-$ \\
& NA class & $n a-$ \\
& A class & $a-$ \\
& GU class & $g u-$ \\
& MA class & $m a-$ \\
\hline
\end{tabular}

(Heath 1978: Ch. 4) 
his mother and her siblings belong. Each moiety uses its own kinship terminology, as presented in Table 9. Thus, a man calls his sons and daughters $y u$ murr as they belong to his moiety, but a woman calls her sons dyuway and her daughters nguudhurr (indicated in bold in Table 9), because they belong to the other moiety.

Table 9. Simplified partial Guugu Yimidhirr kinship terminology.

\begin{tabular}{|c|c|c|c|c|}
\hline \multirow{2}{*}{ Generation } & \multicolumn{2}{|l|}{ My moiety } & \multicolumn{2}{|l|}{ Their moiety } \\
\hline & Masculine & Feminine & Masculine & Feminine \\
\hline+2 & & $m i$ & ngadhi & $b a b i$ \\
\hline+1 & $\begin{array}{l}\text { mugagay } \\
\text { biiba }\end{array}$ & biimuur & mugur & ngamu \\
\hline 0 & $\begin{array}{l}\text { yaba } \\
\text { garga }\end{array}$ & $\begin{array}{l}\text { gaanhaal } \\
\text { dyin-gurr }\end{array}$ & gaanyil, dunhu & dyiiral \\
\hline-1 & \multicolumn{2}{|c|}{ yumurr } & dyuway & nguudhurr \\
\hline-2 & \multicolumn{2}{|c|}{ gaminhdharr } & \multicolumn{2}{|c|}{ ngadhinil } \\
\hline
\end{tabular}

(Haviland 1979: 214)

\subsubsection{Emotions of the speaker towards a referent}

Although emotions of the speaker are often expressed by using evaluative (or expressive) morphemes (Körtvélyessy 2012; Steriopolo 2016; Stump 1993a; and many others), a switch in gender can also be used to indicate the speaker's emotions. In some languages, feminine gender is associated with positive emotions and masculine with negative emotions, while in others, the opposite is the case. For example, in Oromo, an affectionate attitude correlates with the feminine gender, while a pejorative attitude correlates with the masculine gender, as shown in (16) and (17). See also example (2) above for the Harar dialect of Oromo.
Waan-ti
tun jiidh-tuu.
thing-FEM.SUBJECT.TOPIC this.FEM wet-FEM
'This (cute little) thing is wet.' 


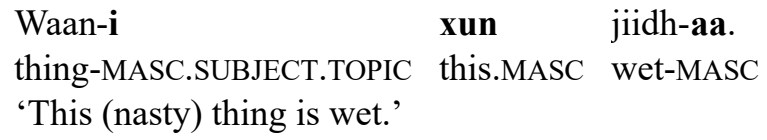

(Aikhenvald 2016: 45)

Unlike in Oromo, in Russian (Slavic), one can refer to a woman affectionately with a masculine gender form. For example, in (18), the masculine diminutive suffix $-o k$ is used with the female name Liza, which triggers masculine grammatical agreement with the adjective xorosh-ij 'good'. According to Doleschal and Schmid (2001: 265), such usage occurs in motherese and the "language of love," thus, it has an endearing function.

$$
\begin{array}{llll}
\text { Liz-ok } & \text { u } & \text { nas } & \text { xorosh-ij. } \\
\text { Liza-MASC.SG } & \text { with } & \text { us } & \text { good-MASC.SG } \\
\text { 'Little Lizzy is a good sport.' (referring to a female) }
\end{array}
$$

(Doleschal and Schmid 2001: 265)

In contrast to Russian, in Manambu, any use of the opposite gender - feminine for a man and masculine for a woman - is derogatory (Aikhenvald 2016). Should it occur, people would "feel downgraded to the level of inanimate objects" (Aikhenvald 2016: 102), which are usually classified by size and shape. Utterances such as that in (19) would be considered extremely rude and offensive by the speakers of Manambu.

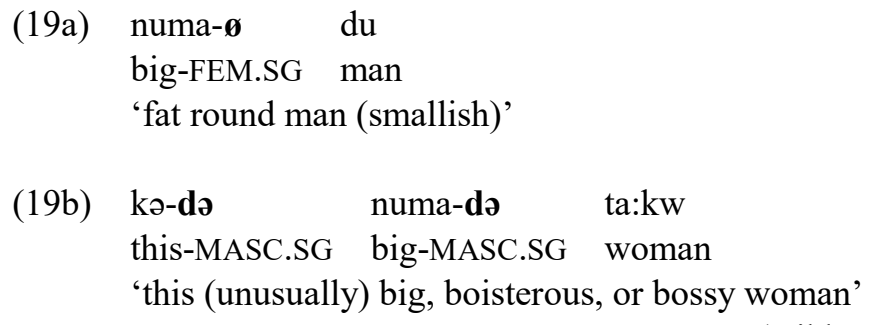

(Aikhenvald 2012: 53, 54)

The data from Tigre (an Afroasiatic language spoken in northeastern Africa) present an interesting case of gender switch. Affectionate and pejorative singular derivations are formed by means of the feminine suffix -ät and the masculine suffix -ay, among other suffixes (Stump 1993a). The resulting derivation receives a positive interpretation if the gender of the suffix matches 
the gender of the base, as in (20b) and (21b). A negative interpretation is achieved when there is no match between the gender of the suffix and that of the base, as presented in (20c) and (21c).

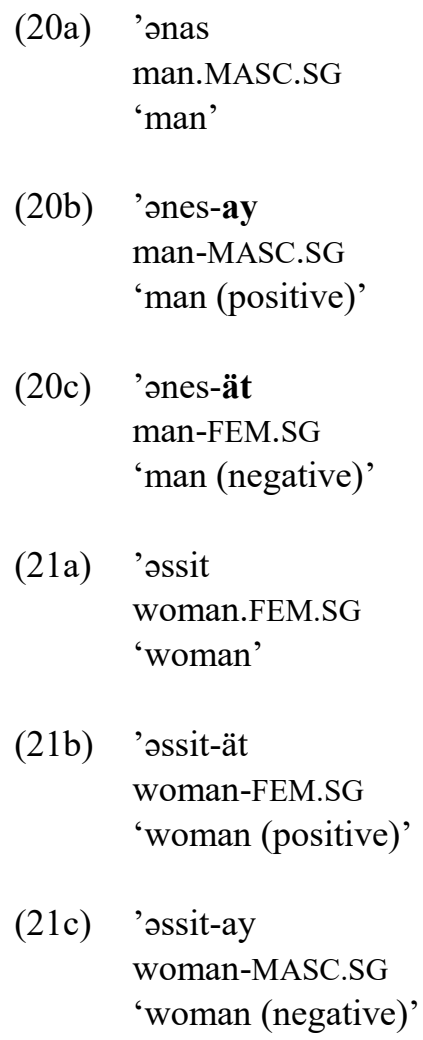

To summarize, the cross-linguistic data show a multitude of functions of genders. For example, in Oromo, a switch from feminine to masculine gender expresses a negative attitude, while in Russian, it expresses a positive attitude. In Manambu and Tigre, any gender switch of a [+human] noun seems to express a derogatory function. However, what all these languages have in common is the use of gender switch for evaluative purposes in order to express the speaker's emotions. 


\section{Formal predictions}

\subsection{Double-marking for gender}

When $n$-gender coexists with $D$-gender in a single language, we expect that double-marking for gender should be possible. This prediction is borne out across languages. For example, double-marking is present in many Bantu (e.g., Kikuyu, Ndali, Nyanja, Shona, Swahili) and Australian (e.g., Anindilyakwa, Nungali, Unggumi, Yanyuwa) languages.

For example, consider Bantu languages. In Kikuyu (a Bantu language spoken in Kenya), if a noun of class I/II (singular/plural) is diminutivized, it receives the diminutive class XII/XIII prefixes that can attach outside the original class I/II prefixes (see (22a, b) for a singular noun and (23) for a plural noun) (Stump 1993a, 1993b). In such cases, the outermost prefix determines grammatical agreement, as shown in (23).

(22a) $\boldsymbol{m} \hat{\boldsymbol{u}}$-raata

I-friend

'friend'

(22b) ka-mû-raata

XII-I-friend

'small friend'

(Stump 1993a: 8-9)

(23) tũ-mĩ-rũũthi tũ-nini

XIII-II-lion XIII-little

'little lions'

(Stump 1993b: 174)

Shona (a Bantu language spoken in Zimbabwe) also uses a similar strategy (Fortune 1955), as illustrated in (24).

(24a) my-ana

I-child

'child'

(24b) ka-my-ana

XIII-I-child

'small child'

(Fortune 1955: 95) 
It is important to note that prefixes occurring in the outermost position are usually associated with evaluation and include diminutives, augmentatives, and pejoratives (see Vail 1974: 24). This corresponds to the evaluative function of $D$-gender.

\subsection{Mixed gender agreement}

Furthermore, when $n$-gender and $D$-gender coexist within a single language, we expect that mixed gender agreement should be possible. This prediction is borne out across languages. Mixed gender agreement is found in many languages of the world (see Corbett 1991: Ch.8 for a detailed description). For example, in Chichewa (a Bantu language spoken in Malawi) the word for 'hero' usually belongs to the noun class $9 / 10$ (single/plural) (what Corbett calls "syntactic agreement"), as in (25a). However, when referring to a male hero, it can also take 1/2 (single/plural) agreements (according to Corbett, "semantic agreement"), as in (25b), because the $1 / 2$ classes typically denote male humans. In $(25 \mathrm{c})$, there is mixed gender agreement (both syntactic and semantic), in which the word for 'our' takes the class 9 prefix $y$-, and the word for 'first' takes the class 1 prefix $w$-.

(25a) ngawazi $\mathbf{y}$-athu $\mathbf{y}$-oyamba

hero 9-our 9-first

'our first hero'

(25b) ngawazi w-athu w-oyamba

hero 1-our 1-first

'our first hero'

(25c) ngawazi $\mathbf{y}$-athu w-oyamba

hero 9-our 1-first

'our first hero'

(Corbett 1991: 239)

Heine (1982: 194) notes that this is characteristic for many African languages - mixed agreement can be used productively with animate nouns. For example, in Swahili (Bantu), the animate noun ki-faru 'rhino' usually belongs to the noun class VII, but it can also be used with the noun class I, which typi- 
cally denotes human beings. The example in (26a) illustrates mixed agreement with both class VII and class I. However, inanimate nouns, such as $k i$ tabu 'book', for example, can only trigger their own class agreement (class VII in 26b).
(26a) ki-faru $\mathbf{m}$-kubwa
VII-rhino I-big
'a big rhino'
(25b) ki-tabu ki-kubwa
VII-book VII-big
'a big book'

(Heine 1982: 194, 195)

To illustrate more examples, in Manambu (Papuan), the word top 'village' is usually feminine, but when the speaker views a village as unusually large, the masculine form can be used, because in Manambu, the masculine gender correlates with the large size. The example in (27) presents mixed agreement, in which the word tap 'village' triggers both feminine and masculine agreements.

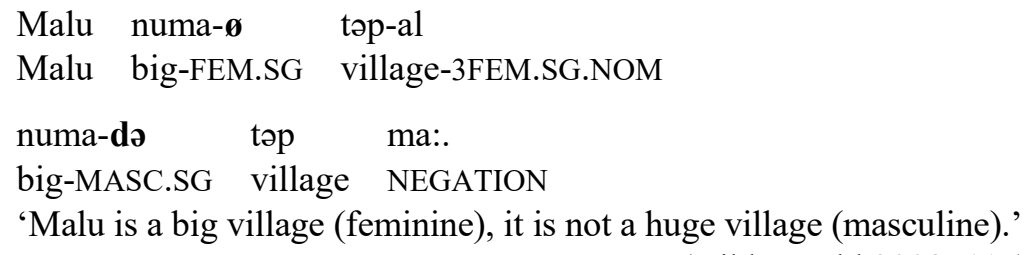

(Aikhenvald 2008: 117)

Furthermore, for Cree (an Algonquian language spoken in Canada) narratives, mixed animate-inanimate gender agreement has been described (Goddard 2002: 204). For example, in a Cree text about a rolling skull, the usually inanimate noun ostikwan 'head' can trigger mixed agreement when referring to a severed head that is able to talk, as given in (28).

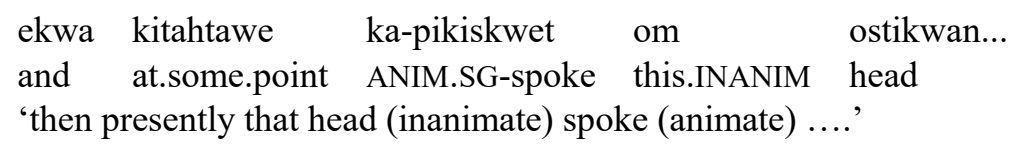


In French (Romance), the well-known example in (29) also presents a case of mixed agreement. The word Majesté 'majesty' is feminine, as shown in (29a), but when it refers to a male individual, mixed agreement (both feminine and masculine) can be used, as in (29b).

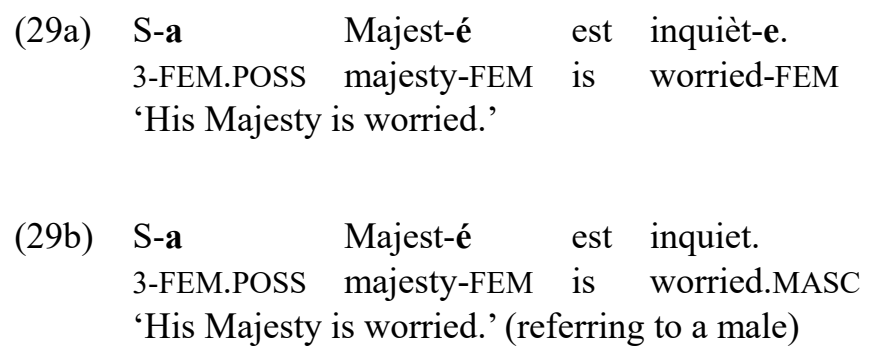

(Matushansky 2013: 273)

In Russian, we observe the opposite - a masculine noun can trigger mixed agreement when it refers to a female individual. For example, the word for 'doctor' (like many profession nouns) is masculine, as shown in (30a). However, when referring to a female doctor, mixed agreement is possible, as in (30b). See Steriopolo (2018b) for a morphosyntactic analysis of mixed gender agreement in Russian.

(30a) Vrach

prishl-a.

doctor.MASC.SG arrived-FEM.SG

'The doctor has arrived.' (referring to a female)
(30b) Nash-a vrach $\quad-$ umnica.
our-FEM.SG doctor.MASC.SG clever.person

'Our doctor is a clever person.' (referring to a female)

(Matushansky 2013: 273)

\subsection{Co-existence of separate gender systems}

As cross-linguistic data show, separate, independent gender systems can coexist within a single language. This is the case for a number of African, South American, Papuan, and Australian languages (see Aikhenvald 2000: $67)$. 
Heine (1982: 195) observes that "most African languages have more than one set of agreement markers." He proposes calling the two basic sets "pronominal" and "nominal" agreements. The pronominal agreement set (which correspond to what I call $D$-gender) generally occurs with pronouns. Heine (1982) notes that pronominal agreement is more likely to have a semantic base compared to nominal agreement, which is typically syntactic, as, for example, in Iraqw (South Cushitic; see Heine 1982: 195, 196).

For instance, Turkana has two separate sets of agreement markers: a nominal and a pronominal set, as presented in Table 10. The nominal markers occur on nouns, indefinite adjectives, and numerals. All other categories (e.g., relative pronouns) use the pronominal gender markers.

Table 10. Turkana nominal and pronominal gender markings.

\begin{tabular}{llll}
\hline & & Nominal & Pronominal \\
\hline Singular & Masculine & $e$ & $l(o)$ \\
& Feminine & $a$ & $n(a)$ \\
& Common & $i$ & $n(i)$ \\
\hline Plural & Feminine & $\eta a$ & $n(u)$ \\
& Non-feminine & $\eta i$ & $l(u)$ \\
\hline
\end{tabular}

(Heine 1982: 195, 203)

Heine (1982) also mentions that many African languages (e.g., Animere, Zande, ! Xu) have lost their nominal agreement set, but retained their pronominal agreement set. For example, in Zande (a Niger-Congo language spoken in the northeast of the Democratic Republic of Congo and western South Sudan), there is no nominal agreement; gender distinctions are exclusively pronominal (Heine 1982: 209). There are two different sets of pronominal gender markers. Set I is used, for example, with demonstrative pronouns, but not with demonstrative adjectives, as shown in (31), while set II is used with self-standing and subject personal pronouns.

(31a) $g l-k J-r \varepsilon$ 'this one (MASC)'

(31b) gi- rí-rè 'this one (FEM)' 
Many languages of South America (e.g., Arawak, Tucano, Yagua) also display two different gender systems: (i) a smaller system for personal pronouns and articles that involves sex and animacy distinctions, and (ii) a larger system for adjectival and numeral modifiers that consists of several dozen noun classes (Aikhenvald 2000: 69). For example, Baniwa (North Arawak; see Aikhenvald 2000: 69) uses two different systems of gender: (i) feminine/nonfeminine gender used with demonstratives and personal pronouns, and (ii) a closed set of 44 noun classes used with adjectives, as shown in (32).

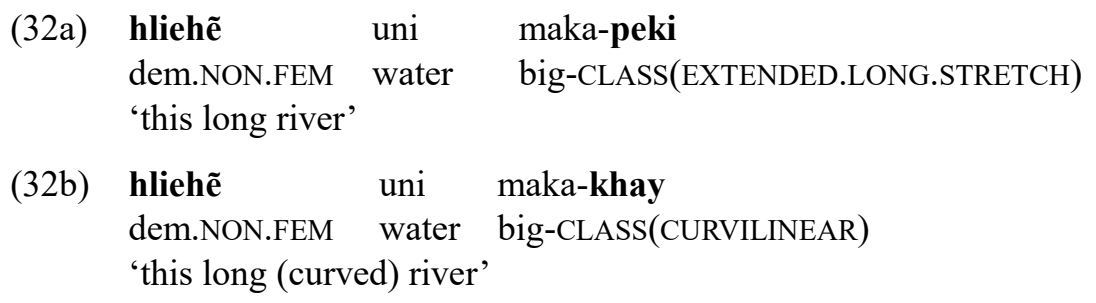

(Aikhenvald 2000: 69)

The co-existence of separate gender and noun class systems has also been described in a number of Papuan languages, including Burmeso (Donohue 2001, Foley 2000), Motuna (Foley 2000), and Mian (Fedden 2011).

In Burmeso (or Taurap, an isolate, spoken along the mid Mamberamo River in Papua province, Indonesia), noun classes are indicated by verbal prefixes, whereas gender is indicated by verbal suffixes (Donohue 2001), such as in (33). There are six noun classes and three main genders (masculine, feminine, neuter) in Burmeso. Examples such as (33) and (34) below are also relevant for double-marking of gender, discussed in $\S 5.1$ above.

$$
\begin{array}{lll}
\text { Da } & \text { aguro } \quad \text { j-akasu-d } & \text { j-ihwa. } \\
\text { 1SG head.PL } & \text { IV.SG/PL-many-MASC/FEM.PL } & \text { IV.SG/PL-see.PAST } \\
\text { 'I saw many heads.' } &
\end{array}
$$

(Donohue 2001: 104)

Donohue (2001: 108) observes that masculine nouns tend to cluster in class I, while feminine nouns tend to cluster in class II. However, the two systems of class and gender are separate and there are mismatches. Thus, the nouns in (34) belong to class II, but their gender varies: it is masculine in (34a), feminine in (34b), and neuter in (34c). 
(34a) Da n-asna-b.

SG CLASSII.SG-white-MASC.SG

'I am white.'

(34b) Samtunar n-asna-n.

knife.SG CLASSII.SG-white-FEM.SG

'(The) knife is white.'

(34c) Akeaway n-asna-o.

cockatoo.SG CLASSII.SG-white-NEUTER.SG

'(The) cockatoo is white.'

(Donohue 2001: 109)

\subsection{Summary}

It has been proposed that the cross-linguistic differences related to fixed vs. variable gender marking are related to two different syntactic positions which the category "gender" occupies across languages. It has been further proposed that fixed gender occupies the nominal head, $n$, while variable gender occupies the determiner head, $D$. This makes certain functional and formal predictions. First, positioning of variable gender on $D$ predicts the correlation of $D$-gender with deixis (e.g., on differences in the sex of speech participants) and referentiality (e.g., on differences in the size and shape of the referent), whereas there is no such correlation with $n$-gender. Second, if both genders co-exist within a single language, it could be predicted that in such languages, double-marking for gender should be possible, as well as mixed gender agreement and two separate gender systems (e.g., pronominal and nominal genders) which are independent of each other. All these possibilities have been shown to exist in many of the world's languages.

\section{Conclusions}

The paper has discussed two different types of the syntactic category "gender": nominal gender (or $n$-gender) and determiner gender (or $D$-gender). Focusing on $D$-gender across languages, this work has proposed the following two characteristics which distinguish it from $n$-gender: (i) variation and 
(ii) discourse dependency. Based on the syntactic structure proposed for these two types of gender, we could make certain formal and functional predictions that were shown to be correct cross-linguistically.

\section{References}

Acquaviva, P. 2018. Categorization as noun construction: Gender, number, and entity types. In: Mathieu, É., M. Dali and G. Zareikar (eds.), Gender and noun classification. Oxford: Oxford Linguistics. 41-66.

Acquaviva, Paolo 2009: Roots and lexicality in distributed morphology. In: Galani, A., D. Redinger and N. Yeo (eds.), York Papers in Linguistics 2(10): York-Essex Morphology Meeting. 1-21.

Aikhenvald, A. 2000. Classifiers: A typology of noun categorization devices. Oxford: Oxford University Press.

Aikhenvald, A. 2008. The Manambu language of East Sepik, Papua New Guinea. Oxford: Oxford University Press.

Aikhenvald, A. 2012. Round women and long men: Shape, size, and the meanings of gender in New Guinea and beyond. Anthropological Linguistics 54(1). 33-86.

Aikhenvald, A. 2016. How gender shapes the world. Oxford: Oxford University Press.

Alexiadou, A. 2004. Inflection class, gender, and DP internal structure exploration. In: Müller, G., L. Gunkel and G. Zifonun (eds.), Nominal inflection. Berlin: Mouton de Gruyter. 21-50.

Amha, A. 2001. The Maale language. Leiden: Research School of Asian, African, and American Studies.

Armoskaite, S. and M. Wiltschko. 2012: There are many ways to be gendered. In: Caxaj, P. (ed.), Proceedings of the 2012 Annual Conference of the Canadian Linguistic Association. 1-14.

Clamons, R. 1995. How recent contact erased ancient traces in the gender systems of the Oromo dialects. Proceedings of the Twenty-First Annual Meeting of the Berkeley Linguistics Society. 389-400.

Corbett, G. 1991. Gender. Cambridge, UK: Cambridge University Press.

Corbett, G. and S. Fedden. 2016: Canonical gender. Journal of Linguistics 52. 495531.

di Garbo, F. 2013. Evaluative morphology and noun classification: A cross-linguistic study of Africa. SKASE Journal of Theoretical Linguistics 10(1). 114-136.

Dixon, R.M.W. 1982. Where have all the adjectives gone? And other essays in semantics and syntax. Berlin: De Gruyter.

Doleschal, U. and S. Schmid. 2001. Doing gender in Russian: Structure and perspective. In: Hellinger, M. and H. Bußmann (eds.), Gender across languages: The linguistic representation of women and men. Amsterdam: Benjamins. 253-282. 
Donohue, M. 2001. Animacy, class and gender in Burmeso. In: Pawley, A., M. Ross and D. Tryon (eds.), The boy from Bundaberg: Studies in Melanesian linguistics in honour of Tom Dutton. Canberra: Pacific Linguistics. 97-115.

Dunn, M. 2014. Gender determined dialect variation. In: Corbett, G.G. (ed.), The expression of gender. Berlin: De Gruyter. 39-68.

Edenmyr, N. 2004. The semantics of Hadza gender assignment: A few notes from the field. Africa \& Asia 4. 3-19.

Fassi Fehri, A. 2015. The semantic diversity of Arabic gender. Brill's Journal of Afroasiatic Languages and Linguistics 8(1). 154-199.

Fedden, S. 2011. A grammar of Mian. Berlin: De Gruyter Mouton.

Fedden, S. and G.G. Corbett. 2017. Gender and classifiers in concurrent systems: Refining the typology of nominal classification. Glossa: A Journal of General Linguistics 2(1). 1-47.

Ferrari, F. 2005. A syntactic analysis of the nominal systems of Italian and Luganda: How nouns can be formed in the syntax. (PhD dissertation, New York University.)

Fillmore, C.J. 1997 [1971]. Lectures on deixis. Stanford: CSLI Publications.

Foley, W. 2000. The languages of New Guinea. Annual Review of Anthropology 29. $357-404$.

Fortune, G. 1955. An analytical grammar of Shona. London: Longman, Green and Co.

Gerdts, D. 2013. The purview effect: Feminine gender on inanimates in Halkomelem Salish. In: Cathcart, C., I.-H. Chen, G. Finley, S. Kang, C.S. Sandy and E. Stickles (eds.), Proceedings of the Thirty-Seventh Annual Meeting of the Berkeley Linguistics Society. Berkeley: Berkeley Linguistics Society. 417-426.

Goddard, I. 2002. Grammatical gender in Algonquian. In: Wolfart, H.C. (ed.), Papers of the Thirty-Third Algonquian Conference. Winnipeg: University of Manitoba. 195-231.

Grinevald, C. 2000. A morphosyntactic typology of classifiers. In: Senft, G. (ed.), Systems of nominal classification. Cambridge: Cambridge University Press. 5088.

Haas, M.R. 1944. Men's and women's speech in Koasati. Language 20. 142-149.

Haviland, J. 1979. How to talk to your brother-in-law in Guugu-Yimidhirr. In: Shopen, T. (ed.), Languages and their speakers. Cambridge, MA: Winthrop. 160-239.

Heath, J. 1978. Ngandi Grammar, texts and dictionary. Canberra: Australian Institute of Aboriginal Studies.

Heine, B. 1982. African noun class systems. In: Seiler, H. and C. Lehmann (eds.), Apprehension: Das sprachliche Erfassen von Gegenständen (vol. 1). Tübingen: Gunter Narr Verlag. 189-216.

Kihm, A. 2005. Noun class, gender, and the lexicon-syntax-morphology interfaces: A comparative study of Niger-Congo and Romance languages. In: Cinque, G. and R.S. Kayne (eds.), The Oxford handbook of comparative syntax. Oxford: Oxford University Press. 459-512.

Körtvélyessy, L. 2012. Evaluative morphology from cross-linguistic perspective. (PhD dissertation, University of Košice.) 
Kramer, R. 2012. Gender in Amharic: A morphosyntactic approach to natural and grammatical gender. Language Sciences 43. 593-634.

Lecarme, J. 2002. Gender 'polarity': Theoretical aspects of Somali nominal morphology. In: Boucher, P. and M. Plénat (eds.), Many morphologies. Somerville, MA: Cascadilla Press. 109-141.

Lowenstamm, J. 2008. On little n, root, and types of nouns. In: Hartmann, J., V. Hegedus and H. van Riemsdjik (eds.), The sounds of silence: Empty elements in syntax and phonology. Amsterdam: Elsevier. 105-144.

Matushansky, O. 2013. Gender confusion. In: Lai-Shen Cheng, L. and N. Corver (eds.), Diagnosing syntax. Oxford: Oxford University Press. 271-294.

Osborne, C.R. 1974. The Tiwi language: Grammar, myths, and dictionary of the Tiwi Language spoken on Melville and Bathurst Islands, Northern Australia. Canberra: Australian Institute of Aboriginal Studies.

Payne, D.L. 1998. Maasai gender in typological perspective. Studies in African Linguistics 27(2). 159-175.

Pesetsky, D. 1995. Zero syntax: Experiencers and cascades. Cambridge, MA: MIT Press.

Pesetsky, D. 2013. What is to be done? Paper presented at the LSA Annual Meeting, January 4.

Pet, W.J.A. 2011. A grammar sketch and lexicon of Arawak (Lokono Dian). SIL EBooks, vol. 30. SIL International.

Seifart, F. 2010. Nominal classification. Language \& Linguistics Compass 4(8). 719 736.

Steriopolo, O. 2016. Expressives across languages: Form/function correlation. Annual Review of Linguistics 2. 293-324.

Steriopolo, O. 2017. Nominalizing evaluative suffixes in Russian: The interaction of declension class, gender, and animacy. Poljarnyj vestnik: Norwegian Journal of Slavic Studies 20. 18-44.

Steriopolo, O. 2018a: Morphosyntax of gender in Russian sex-differentiable nouns. Journal of Slavic Linguistics 26(2). 307-335.

Steriopolo, O. 2018b: Mixed gender agreement in the case of Russian hybrid nouns. Questions and Answers in Linguistics 5(1). 1-15.

Steriopolo, O. and M. Wiltschko. 2010: Distributed gender hypothesis. In: G. Zybatow, P. Dudchuk, S. Minor, E. Pshehotskaya (eds.) 2010: Formal Studies in Slavic Linguistics. New York: Peter Lang, 155-172.

Stump, G. 1993a. How peculiar is evaluative morphology? Journal of Linguistics 29, $1-36$.

Stump, G. 1993b. Reconstructing morphology: The case of Bantu prefixation. Linguistic Analysis 23, 169-204.

Sumbuk, K.M. 1999: Morphosyntax of Sare. (PhD dissertation, University of Waikato.

Svenonius, P. 2008. The position of adjectives and other phrasal modifiers in the decomposition of DP. In: McNally, L. and C. Kennedy (eds.), Adjectives and adverbs: Syntax, semantics, and discourse. Oxford: Oxford University Press. 1642. 
Vail, L. 1974. The noun classes of Ndali. Journal of African Languages 11(3). 2147.

Corresponding author:

Olga Steriopolo

Independent scholar

olgasteriopolo@hotmail.com 